Lepr Rev (1993) 64, 143-149

\title{
An epidemiological survey of deformities and disabilities among 14,257 cases of leprosy in 11 counties
}

\author{
ZHANG GUOCHENG, LI WENZHONG, \\ YAN LIANGBIN, YANG ZHONGMIN, \\ CHEN XIANGSHENG, ZHENG TISHENG \\ \& YE GANYUN \\ Institute of Dermatology, CAMS, Nanjing, P.R. of China
}

Accepted for publication 6 November 1992

\begin{abstract}
Summary This study was planned and conducted in Yang Zhou Prefecture, covering 11 counties that were formerly areas with a high prevalence of leprosy. Out of 14,257 leprosy patients, $8122(56.97 \%)$ cases with deformities and disabilities were found. The disability rate is much higher in patients with $\mathrm{MB}$ leprosy $(81 \cdot 15 \%)$ than in PB leprosy (53.04\%). The statistical data and the type of deformities and disabilities are presented. The influences of various host factors and disease factor which cause disability and deformity are discussed.
\end{abstract}

\section{Introduction}

Leprosy produces deformities and disabilities which can leave a permanent mark on the patients and result in stigma. Therefore, disability control is of great importance in a leprosy control programme, and our government is giving more attention to this than ever before. In order to find out the magnitude of the problem - the distribution of disabilities by sex, age and type of leprosy, the distribution of hand, foot and eye deformity according to type, the number of patients requiring reconstructive surgery and/or protective shoesand to draw up the national rehabilitation project, an epidemiological study of disability was carried out in Yang Zhou. This prefecture has 11 counties with a population of more than 10 million.

\section{Material and methods}

The epidemiological survey of disability and deformity was carried out from March 1988 to the end of the year by a team of 55 paramedical workers and doctors in the field and 3 medical supervisors. All were fully trained before the study commenced. Patients with 


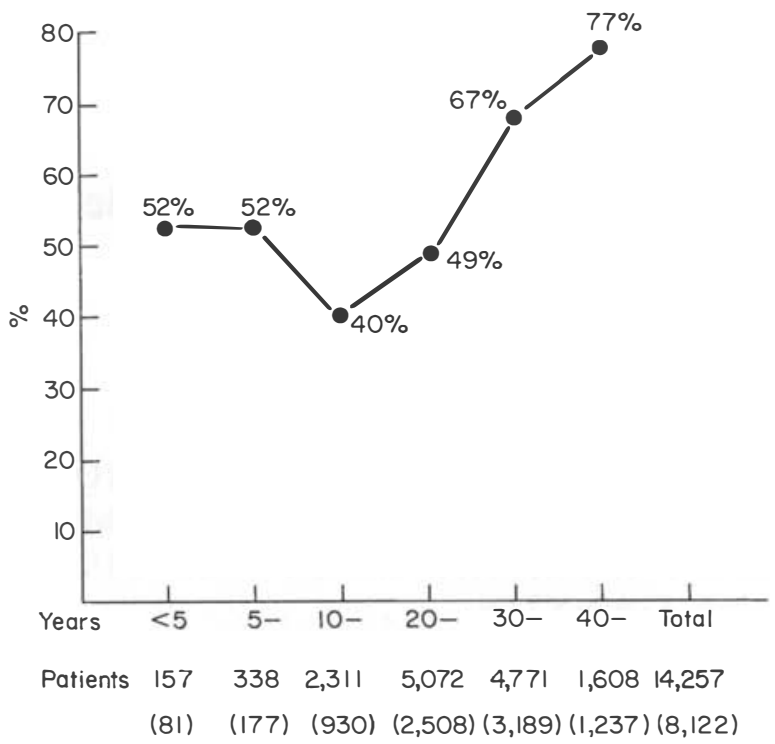

Figure 1. Duration of disease and disability.

deformities and disabilities were assessed according to the grading system recommended by the WHO Expert Committee (1970), with a little modification by us.

Out of 14,257 leprosy patients there were 10,356 males and 3901 females. The largest number of patients were PB (12,256 cases). Most patients had a long leprosy history of 20-29 years, followed by 30-39, 10-19, over 40 years, 5-9 years and less than 5 years in that order (Figure 1). A detailed history of each patient was taken, including the duration of the disease, the origin of complaints, the regularity of treatment, and the origin of deformities and disabilities. Detailed examinations were carried out, both local and systemic, including eyes, nose, face, sensory modalities, motor modalities, ulcers, hand and foot, etc. All the data were stored in a computer.

Table 1. Disabilities by age

\begin{tabular}{|c|c|c|c|c|c|c|c|c|c|}
\hline \multirow[b]{2}{*}{ Age } & \multicolumn{3}{|c|}{ Males } & \multicolumn{3}{|c|}{ Females } & \multicolumn{3}{|c|}{ Total } \\
\hline & $\begin{array}{c}\text { No. of } \\
\text { cases }\end{array}$ & $\begin{array}{l}\text { No. of } \\
\text { disabled }\end{array}$ & $\begin{array}{c}\% \\
\text { disabled }\end{array}$ & $\begin{array}{c}\text { No. of } \\
\text { cases }\end{array}$ & $\begin{array}{l}\text { No. of } \\
\text { disabled }\end{array}$ & $\begin{array}{c}\% \\
\text { disabled }\end{array}$ & $\begin{array}{c}\text { No. of } \\
\text { cases }\end{array}$ & $\begin{array}{l}\text { No. of } \\
\text { disabled }\end{array}$ & $\begin{array}{c}\% \\
\text { disabled }\end{array}$ \\
\hline$<15$ & 11 & 5 & $45 \cdot 45$ & 5 & 2 & $40 \cdot 00$ & 16 & 7 & $43 \cdot 75$ \\
\hline $15-24$ & 45 & 22 & $48 \cdot 89$ & 27 & 10 & $37 \cdot 04$ & 72 & 32 & $44 \cdot 4$ \\
\hline $25-34$ & 329 & 163 & $49 \cdot 54$ & 176 & 91 & $51 \cdot 70$ & 505 & 254 & $50 \cdot 30$ \\
\hline $35-44$ & 2086 & 1229 & $58 \cdot 92$ & 824 & 479 & $57 \cdot 77$ & 2910 & 1708 & 58.69 \\
\hline $45-54$ & 3654 & 2134 & $58 \cdot 40$ & 1137 & 627 & $55 \cdot 15$ & 4791 & 2761 & $57 \cdot 63$ \\
\hline $55-64$ & 2599 & 1551 & $59 \cdot 68$ & 951 & 473 & $49 \cdot 74$ & 3550 & 2024 & $57 \cdot 01$ \\
\hline $65-$ & 1621 & 918 & 56.63 & 772 & 405 & $52 \cdot 46$ & 2393 & 1323 & $55 \cdot 29$ \\
\hline Unknown & 11 & 6 & $54 \cdot 54$ & 9 & 7 & $77 \cdot 78$ & 20 & 13 & $65 \cdot 00$ \\
\hline Total & 10,356 & 6028 & $58 \cdot 21$ & 3901 & 2094 & 53.68 & 14,257 & 8122 & 56.97 \\
\hline
\end{tabular}




\section{Results}

FREQUENCY OF DEFORMITIES AND DISABILITIES

Out of 14,257 cases of leprosy, 8122 cases (56.97\%) were found with deformities or disabilities (Table 1). Males were more often disabled than females ( $58 \cdot 21 \%$ for males, $53.68 \%$ for females - difference significant at $p<0.0001)$.

\section{Disabilities AND AGE (Table 1)}

The older the patient, the more frequent and serious were their disabilities. Males had more disabilities than females.

\section{DISABILITIES IN RELATION TO THE TYPE OF LEPROSY}

The details of disabilities and the type of leprosy are recorded in Table 2 . The percentage of disabled cases varies with type, the highest being the LL group (89.12\%). The disabled percentage among MB $(81 \cdot 15 \%)$ is higher than those among PB $(53.04 \%)$ (difference significant at $p<0.0001$ ). A total of 3734 cases out of 6501 disabled PB leprosy patients $(57 \cdot 44 \%)$ and 863 cases out of 1610 disabled MB patients $(53.60 \%)$ became disabled before the commencement of antileprosy treatment while 1059 cases of PB leprosy and 434 cases of MB leprosy were deformed during or after treatment.

\section{DURATION OF DISEASE AND DISABILITY}

Figure 1 illustrates the number of disabled persons in relation to duration of disease. The disabled rate increased with the length of disease.

\section{PROPORTION OF GRADES 1, 2 AND 3 DISABILITY}

Table 3 shows the proportion of Grades 1, 2 and 3 disability among 8122 disabled casesGrade 3 is the highest $(62 \cdot 04 \%)$.

Table 2. Disabilities by leprosy type

\begin{tabular}{|c|c|c|c|c|c|c|}
\hline Type & $\begin{array}{l}\text { No. of } \\
\text { cases }\end{array}$ & $\begin{array}{c}\text { No. of } \\
\text { disabled }\end{array}$ & $\begin{array}{c}\% \\
\text { disabled }\end{array}$ & $\begin{array}{c}\% \text { disabled } \\
\text { before treatment }\end{array}$ & $\begin{array}{c}\% \text { disabled } \\
\text { during treatment }\end{array}$ & Unknown \\
\hline I & 41 & 16 & $39 \cdot 02$ & $14(87 \cdot 5)$ & 0 & 2 \\
\hline PB TT & 8000 & 3,456 & $43 \cdot 2$ & $2069(59.87)$ & $417(12 \cdot 07)$ & 970 \\
\hline BT & 4215 & 3,029 & $73 \cdot 43$ & $1651(54 \cdot 51)$ & $642(21 \cdot 20)$ & 736 \\
\hline Total & 12,256 & 6,501 & 53.04 & $3734(57 \cdot 44)$ & $1,059(16 \cdot 29)$ & 1,708 \\
\hline BB & 167 & 114 & $68 \cdot 26$ & $62(54 \cdot 39)$ & $22(19 \cdot 30)$ & 30 \\
\hline MB BL & 751 & 546 & $72 \cdot 7$ & $254(46 \cdot 52)$ & $165(30 \cdot 22)$ & 127 \\
\hline $\mathrm{LL}$ & 1066 & 950 & $89 \cdot 12$ & $547(57 \cdot 58)$ & $247(26 \cdot 00)$ & 156 \\
\hline Total & 1984 & 1,610 & $81 \cdot 15$ & $863(53 \cdot 60)$ & $434(26 \cdot 96)$ & 313 \\
\hline Unknown & 17 & 11 & $64 \cdot 71$ & 5 & 0 & 6 \\
\hline
\end{tabular}


Table 3. Proportion of Grades 1, 2 and 3

\begin{tabular}{|c|c|c|c|c|c|c|c|c|}
\hline \multirow{2}{*}{ Grade } & \multicolumn{2}{|r|}{ PB } & \multicolumn{2}{|c|}{ MB } & \multicolumn{2}{|c|}{ Unknown } & \multicolumn{2}{|c|}{ Total } \\
\hline & & & & & & & & \\
\hline 1 & 197 & $(3 \cdot 03)$ & 65 & $(4 \cdot 04)$ & & 0 & 262 & $(3 \cdot 23)$ \\
\hline 2 & 2272 & $(34.95)$ & 305 & $(18.94)$ & 5 & $(45 \cdot 45)$ & 2582 & $(31 \cdot 79)$ \\
\hline 3 & 3695 & $(59 \cdot 91)$ & 1138 & $(70 \cdot 68)$ & 6 & $(54.55)$ & 5039 & $(62.04)$ \\
\hline Facial & 137 & $(2 \cdot 11)$ & 102 & $(6 \cdot 34)$ & & 0 & 239 & $(2 \cdot 94)$ \\
\hline Deformity Total & 6501 & $(100 \cdot 00)$ & 1610 & $(100 \cdot 00)$ & 11( & $(100 \cdot 00)$ & 8122 & $(100 \cdot 00)$ \\
\hline
\end{tabular}

The actual disabilities and deformities of hands, feet and eyes are recorded in Tables 4, 5, and 6 .

Table 4. Actual disabilities and deformities of hands

\begin{tabular}{|c|c|c|c|c|c|}
\hline & PB & MB & Unknown & Total & Bilateral \\
\hline No. of cases & $12,256(\%)$ & $1984(\%)$ & $17(\%)$ & $14,257(\%)$ & \\
\hline Anaesthesia & $2679(21 \cdot 86)$ & $971(48.94)$ & $6(35 \cdot 29)$ & $3656(25 \cdot 64)$ & $1668(11 \cdot 70)$ \\
\hline Mobile claw hand & $3715(30 \cdot 32)$ & $1042(52 \cdot 52)$ & $5(29 \cdot 41)$ & $4762(33.40)$ & $1814(11 \cdot 70)$ \\
\hline Thumb paralysis & $1532(12 \cdot 5)$ & $528(26 \cdot 61)$ & $4(23 \cdot 53)$ & $2064(14 \cdot 48)$ & $882(6 \cdot 19)$ \\
\hline Cracks and wounds & $370 \quad(3.02)$ & $208(10 \cdot 48)$ & & $578 \quad(4.05)$ & $299(2 \cdot 1)$ \\
\hline Slight absorption & $975 \quad(7.96)$ & $323(16 \cdot 28)$ & $1(5 \cdot 88)$ & $1299(9 \cdot 11)$ & $373 \quad(2.62)$ \\
\hline Contractures & $1115(9 \cdot 10)$ & $380(19 \cdot 15)$ & $2(11 \cdot 76)$ & $1497(10 \cdot 50)$ & $495 \quad(3 \cdot 47)$ \\
\hline Wri & 386 & 70 & $1 \quad(5$ & $457 \quad(3 \cdot 21)$ & $73(0.51)$ \\
\hline Stiff joints & $2723(22 \cdot 22)$ & $804(40 \cdot 52)$ & $5(29 \cdot 41)$ & $3532(24 \cdot 71)$ & $1296(9.09)$ \\
\hline Severe absorption & $1270(10 \cdot 36)$ & $482(24 \cdot 29)$ & $2(11 \cdot 76)$ & $1754(12 \cdot 30)$ & $685(4 \cdot 81)$ \\
\hline
\end{tabular}

Table 5. Actual disabilities and deformities of feet

\begin{tabular}{|c|c|c|c|c|c|}
\hline & PB & MB & Unknown & Total & Bilateral \\
\hline No. of cases & $12,256(\%)$ & $1984(\%)$ & $17(\%)$ & $14,257(\%)$ & \\
\hline Anaesthesia & $2223(18 \cdot 14)$ & $1100(55 \cdot 44)$ & $4(23 \cdot 53)$ & $3327(23 \cdot 34)$ & $1570(11 \cdot 01)$ \\
\hline Foot drop & $1911(15 \cdot 60)$ & $321(16 \cdot 18)$ & $5(29 \cdot 41)$ & $2237(15 \cdot 69)$ & $295(2 \cdot 07)$ \\
\hline Cracks, injuries & $283(2 \cdot 31)$ & $127(6 \cdot 4)$ & & $410(2 \cdot 88)$ & $116(0 \cdot 81)$ \\
\hline Simple ulcers & $404(3 \cdot 30)$ & $204(10 \cdot 28)$ & & $608 \quad(4 \cdot 26)$ & $93 \quad(0.65)$ \\
\hline Slight absorption & $705 \quad(5 \cdot 75)$ & $341(17 \cdot 19)$ & & $1046(7 \cdot 34)$ & $391 \quad(2 \cdot 11)$ \\
\hline Fixed equinovarus & $211 \quad(1.72)$ & $143(7 \cdot 21)$ & & $354(2 \cdot 48)$ & $86 \quad(0 \cdot 60)$ \\
\hline Complicated ulcers & $793(6.4)$ & $481(24 \cdot 24)$ & & $1274(8.95)$ & $303 \quad(2 \cdot 13)$ \\
\hline Shortened foot & $998 \quad(8 \cdot 14)$ & $596(30 \cdot 04)$ & & $1594(11 \cdot 20)$ & $500 \quad(4 \cdot 07)$ \\
\hline Amputation & & & & $565 \quad(3.96)$ & \\
\hline
\end{tabular}


Table 6. Actual disabilities of eyes

\begin{tabular}{|c|c|c|c|c|c|}
\hline & PB & MB & Unknown & Total & Bilateral \\
\hline No. of cases & $12,256(\%)$ & $1984(\%)$ & $17(\%)$ & $14,257(\%)$ & \\
\hline Insensitive cornea & $948 \quad(7 \cdot 73)$ & $394(19 \cdot 86)$ & $2(11 \cdot 77)$ & $1344 \quad(9 \cdot 43)$ & $700(4.91)$ \\
\hline Lagophthalmos & $1500(12 \cdot 24)$ & $609(30 \cdot 70)$ & $5(29 \cdot 41)$ & $2114(14 \cdot 13)$ & $900(6 \cdot 31)$ \\
\hline Eversion of lower lid & $736 \quad(6.01)$ & $275(13 \cdot 86)$ & $2(11 \cdot 76)$ & $1013(7 \cdot 11)$ & $409(2 \cdot 87)$ \\
\hline Keratitis E & $588 \quad(4 \cdot 80)$ & $220(11 \cdot 09)$ & & $808 \quad(5 \cdot 67)$ & $297(2 \cdot 08)$ \\
\hline Iridocyclitis & $195(1.59)$ & $136(6 \cdot 85)$ & $1(5 \cdot 88)$ & $332(2 \cdot 33)$ & $150(1.05)$ \\
\hline Blurring vision & $605 \quad(4.95)$ & $281(14 \cdot 16)$ & $3(17 \cdot 65)$ & $889(6 \cdot 24)$ & $372(2 \cdot 61)$ \\
\hline Marked impairment of vision & $206(1.68)$ & $127 \quad(6 \cdot 40)$ & & $333(2 \cdot 34)$ & $92(0 \cdot 65)$ \\
\hline Blindness & $210(1 \cdot 71)$ & $154(7 \cdot 76)$ & $1(5 \cdot 88)$ & $365(2 \cdot 56)$ & $113(0 \cdot 79)$ \\
\hline
\end{tabular}

Table 7. Facial deformities

\begin{tabular}{|c|c|c|c|c|}
\hline & PB & MB & Unknown & Total \\
\hline No. of cases & $12,256(\%)$ & $1984(\%)$ & $17(\%)$ & $14,257(\%)$ \\
\hline \multicolumn{5}{|l|}{ Facial paralysis } \\
\hline lateral & $1289(10 \cdot 52)$ & $290(14 \cdot 62)$ & & $1579(11 \cdot 10)$ \\
\hline bilateral & $284(2 \cdot 32)$ & $176(8.87)$ & & $460 \quad(3 \cdot 23)$ \\
\hline Loss of eyebrow & $97 \quad(0.79)$ & $1173(59 \cdot 12)$ & & $1270(8.91)$ \\
\hline Collapsed nose & $20(0 \cdot 16)$ & $156(7 \cdot 86)$ & & $176(1.23)$ \\
\hline
\end{tabular}

The actual disabilities and deformities of hands, feet and eyes are recorded in Tables 4, 5 and 6.

Some deformities of the hands, feet and eyes may benefit from reconstructive or plastic surgery, such as a mobile claw had (33.40\%), a foot drop (15.69\%), median nerve paralysis of the thumb (14.48\%), wrist drop (3.21\%), lagophthalmos $(14 \cdot 83 \%)$, etc. Other disabilities may be reversed by health education of the patients in hand-, foot-, and eyecare, MCR shoes, protective gloves, and so on.

\section{FACIAL DEFORMITIES}

Table 7 shows various facial deformities which may be suitable for plastic surgery. A total of 744 out of 3488 patients with facial deformities had no deformities of the hands and feet.

\section{Discussion}

In this study the disability rate* $(56.97 \%)$ in Yang Zhou Prefecture is rather high compared to other countries, such as $\mathrm{Rao}^{1} 42.9 \%$; Hasan ${ }^{2} 44.3 \%$; Koticha and Nair (1979) $37 \cdot 1 \%$; Prasad $^{3} 20 \%$; Chawdhary ${ }^{4} 25 \cdot 8 \%$ and Mishra ${ }^{5} 21 \cdot 2 \%$. However, this is

\footnotetext{
* This totals $55 \%$ if Grade 1 is excluded.
} 
lower than that observed by other researchers in China, such as Zheng Tisheng ${ }^{6} 67 \cdot 5 \%$; Zhang Zhengwei ${ }^{7} 73 \cdot 13 \%$ and Song Fuyuan ${ }^{8}$ 63.62\%. Perhaps the assessments were made in different situations or the criteria of disability grading, definition and samples used for study were quite different. For example, the observations of Zheng Tisheng ${ }^{6}$ were carried out in the community and some leprosariums, whereas the observations of Zhang Zhengwei ${ }^{9}$ were made in a leprosy hospital containing many old patients with severe disabilities. Furthermore, their study concerned a series of defaulter patients. Therefore an exact comparison is impossible.

The disability rate rose in older age groups. In the age groups of $35-44,45-54$ and $55-$ 64 , the prevalence of disability and deformity was very high $(58 \cdot 69 \%, 57 \cdot 63 \%$ and $57 \cdot 01 \%$ respectively). This is similar to the results of Bravo, ${ }^{9}$ Noodeen, ${ }^{10}$ and Zheng Tisheng. ${ }^{6}$

In the present study, the disability rate in the male is higher than in the female. This agrees with the data of Kushwah, ${ }^{11}$ Nilakanta Rao ${ }^{12}$ and Bravo. ${ }^{9}$

In this study the lepromatous type of leprosy was more prone to develop deformities and disabilities than the borderline type. The difference of disability rate between PB and MB leprosy is significant $(p<0 \cdot 0001)$. These findings are similar to those reported by Noordeen ${ }^{10}$ and Zheng Tisheng ${ }^{6}$ and can be explained by the widespread and progressive nature of lepromatous leprosy. Other leprosy types are more localized and have a shorter evolution. A shorter duration means less spread of disease, and less involvement of the nerves. Therefore, early detection of the disease and neuritis, and adequate therapy and health education are very important for disability control in a leprosy control programme.

In this study, $57 \cdot 4 \%$ of PB cases and $53 \cdot 60 \%$ of MB cases had developed deformities and disabilities before the commencement of anti-leprosy treatment, which agrees with the observation made by Zheng Tisheng. ${ }^{6}$ This is probably due to late detection and treatment of the disease, and neuritis.

We have observed that the disability rate increased with increased duration of disease. Similar observations have been made by Zheng Tisheng ${ }^{6}$ and Noordeen ${ }^{10}$ etc. We consider the duration of the disease to be a more important factor than the age of patients in causing deformities and disabilities.

There was little difference in the prevalence of anaesthesia of the hands and feet in both types of leprosy (PB, MB), $(25 \cdot 64 \%$ and $23 \cdot 34 \%)$ but the prevalence of anaesthesia in patients with MB leprosy was more than double that of patients with PB leprosy in both hands $(48 \cdot 94 \% / 21 \cdot 86 \%)$ and feet $(55 \cdot 44 \% / 18 \cdot 14 \%)$. These observations agree with those made by Prasad ${ }^{3}$ and Zheng Tisheng. ${ }^{6}$ Of 8122 cases disabled in this study, 3656 cases had insensitive hands and 3327 cases had insensitive feet, needing protective gloves/shoes. Education in self-care of the hands and feet is necessary to prevent patients' hands and feet suffering further injury and wounds, etc.

The observation of various types of hand deformities, foot deformities and eye disabilities in this study is basically in agreement with the observations of Zheng Tisheng. ${ }^{6}$ However, the amputation rate in this study is much higher than that observed by any other researcher. The reason is not known.

The incidence of facial deformities was very low and not comparable with those of the hands and feet, which corresponds to the observation made by Zheng Tisheng. ${ }^{6}$

In this study, 10-25 of 8122 disabled cases are suitable for consideration for possible reconstructive or plastic surgery. However, patients' attitudes during the survey demonstrate that the majority $(58 \cdot 54 \%)$ would ref use any surgical treatment. Education 
of these patients is therefore essential for their rehabilitation. Analysis of disability and deformity in this study demonstrated that health education in the self-care of hands, feet and eyes, and protective shoes, etc. had a greater potential to reduce disability in leprosy than reconstructive and plastic surgery.

\title{
References
}

1 Rao et al. Int J Lepr, 1970; 38: 1-11.

2 Hasan S. Lepr India, 1977; 49(3): 393-9.

3 Prasad S. Lepr India, 1981; 53(4): 626.

${ }^{4}$ Chawdhary RC. Lepr India, 1981; 53: 259-65.

5 Mishra B et al. Ind J Lepr, 1988; 60(2): 260-6.

${ }^{6}$ Zheng Tisheng et al. China Lepr J, 1988; 4(4): 198-204.

7 Zhang Zhengwei. China Lepr J, 1987; 3(3): 160.

${ }^{8}$ Song Fuyuan et al. China Lepr J, 1989; 5(3): 152.

9 Bravo, et al. Lepr Rev, 1977; 48: 247-60.

10 Noordeen SK et al. Int J Lepr, 1966; 34: 159-69.

11 Kushwah SS et al. Lepr India, 1981; 53: 240-8.

12 Nilakanta Rao et al. Lepr India, 1980; 52: 236-44.

Une enquête épidémiologique des difformités et des infirmités dans 14.257 cas de lèpre dans 11 départements

\author{
Zhang Guocheng, Li Wenzhong, Yan Liangbin, Yan Zhongmin, \\ Chen Xiangsheng, Zheng Tisheng et Ye Ganyun
}

Résumé Cette étude a été planifiée et exécutée à la Préf ecture de Yang Zhou couvrant 11 départements qui étaient auparavant des régions où la lèpre était fréquente. Sur 14.257 patients lépreux, 8.122 cas $(56,97 \%)$ de difformités et d'infirmités ont été observés. Le taux d'infirmités était bien plus élevé chez les lépreux MB $(81,15 \%)$ que chez les lèpreux PB $(53,04 \%)$. Les données statistiques e tle type de difformités et infirmités sont présentés. L'influence des divers facteurs de l'hôte et le facteur maladie qui causent l'infirmité et la difformité sont discutés.

\section{Un estudio epidemiológico de las deformidades y deshabilidades entre 14.257 casos de la lepra en 11 condados}

\author{
Zhang Guocheng, Li Wenzhong, Yan Liangbin, Yang Zhongmin, \\ Chen Xiangsheng, Zheng Tisheng y Ye Ganyun
}

Resumen Este estudio fue preparado y realizado en 11 condados en la Pref ectura de Yang Zhou, anteriormente zonas en que había una prevalencia alta de la lepra. De 14.257 pacientes de la lepra, se encontraron 8.122 $(56,97 \%)$ casos de deformidades y deshabilidades. El porcentaje de deshabilidades es mucho más en los pacientes con lepra multibacilar $(81,15 \%)$ que en el paucibacilar $(53,04 \%)$. Se presentan los datos estadísticos y los tipos de deformidad y deshabilidad. Se discuten los efectos de varios factores de huésped y de factor de enfermedad que causan deshabilidades y deformidades. 